\title{
Phospholipid Phosphatase 1
}

National Cancer Institute

\section{Source}

National Cancer Institute. Phospholipid Phosphatase 1. NCI Thesaurus. Code C34075.

Phospholipid phosphatase 1 (284 aa, $32 \mathrm{kDa}$ ) is encoded by the human PLPP1 gene.

This protein plays a role in both the dephosphorylation of phospholipids and regulation of signaling. 